\title{
ELECTRIC CHARGING STATIONS SPATIAL DISTRIBUTION MODELS FOR ELECTRIFIED VEHICLES: A BRIEF REVIEW
}

\author{
Allison Amorim do Nascimento ${ }^{\text {, }}$ PhD Lílian Lefol Nani Guarieiro ${ }^{2}$, Sandro Guerreiro \\ Ferreira Nevesa
}
a Professional Masters in Sustainable Development, Centro Universitário SENAI CIMATEC, Brazil

\begin{abstract}
Electrification in the automotive market is at full speed globally which makes the infrastructure and distribution planning of charging stations important in order to accommodate this growing demand. This work aimed to systematically review the literature on electric charging stations spatial distribution models for electrified vehicles. Different periodicals were examined to determine the number of articles published on this subject as well as to list where the main researches are being performed in the world. As a result, the main variables, mathematical and computational methods used for modelling the spatial distribution proposals are listed. In conclusion, this systematic review can support the development of new electric charging stations spatial distribution models for electrified vehicles as a summary on the state of the art on this matter.
\end{abstract}

Keywords: Charging stations; Location; Distribution; Infrastructure; Electric vehicles.

\section{MODELOS DE DISTRIBUIÇÃO ESPACIAL DE ESTAÇÕES DE RECARGA ELÉTRICA PARA VEÍCULOS ELETRIFICADOS: UMA BREVE REVISÃO}

Resumo: A eletrificação no mercado automotivo está a toda velocidade em todo o mundo, o que torna importante o planejamento de infraestrutura e distribuição das estações de recarga para acomodar essa demanda crescente. Este trabalho teve como objetivo revisar sistematicamente a literatura sobre modelos de distribuição espacial de estações de carregamento elétrico para veículos eletrificados. Diferentes periódicos foram examinados para determinar o número de artigos publicados sobre o assunto e para listar onde as principais pesquisas estão sendo realizadas no mundo. Como resultado, são listadas as principais variáveis, métodos matemáticos e computacionais usados para modelar as propostas de distribuição espacial. Em conclusão, esta revisão sistemática pode apoiar o desenvolvimento de novos modelos de distribuição espacial de estações de carregamento elétrico para veículos eletrificados como um resumo do estado da arte sobre esse assunto.

Palavras-chave: Estações de recarga; Localização; Distribuição; Infraestrutura; Veículos elétricos. 


\section{INTRODUCTION}

The automotive market has been aggressively dealing with the migration from fuel to electric consumption on its products for more than two decades now. Several variables have contributed to this movement on the past few years; especially due to environmental global goals, massive government support is one of the major contribution variables. Electric vehicles (EV) annual sales increased from just 2 to over 753 thousand worldwide over the past ten years [1]. The projections for EV market share vary among different studies; however, it is a consensus that it will increase on high factors within the next years [1-4]. According to the forecasting model elaborated by Kapustin and Dmitry (2020), by 2040 the number of electric vehicles will increase by a factor of 60-70, compared to 2016 and reach from 12 to $28 \%$ of global fleet [1]. Lieven and Rietmann (2020) model is even more aggressive, indicating that by 2035 , the EV market share is expected to reach $42.5 \%$ worldwide [4].

The growing EV market is demanding new strategies for vehicle electric recharging, not only in terms of charging technologies but also in terms of planning and management of such high-volume market. To follow the current volume prospects, it is mandatory to re-think the whole business model of vehicle fueling strategy used across the globe. More intensely in the last decade, theoretical studies have been conducted to develop models to optimize the placing strategy of charging stations to better suit customers and stakeholders [5-32]. Academic articles have also been conducted to develop strategies for creating intelligent charging grids, taking into account different parameters like costs, minimization of distances, charging technologies and intelligent V2G (vehicle-to-grid) and G2V (grid-to-vehicle) energy management [6,33-35].

Development of electric charging stations spatial distribution models for electrified vehicles is a key factor to the successful deployment of electric vehicles into the market. There are several models available and both academy and industry have been spending energy on the charging station location problem in the last decade. Based on this context, this work aimed to perform a brief systematic literature review on electric charging stations spatial distribution models for electrified vehicles to drive new researchers on this topic and as a comprehensive data for beginners.

\section{METHODOLOGY}

Different scientific databases were explored to determine the number of articles published on electric charging stations spatial distribution models for electrified vehicles as well as to list where the main researches are being performed in the world. With the results returned from the explorations, the main variables, mathematical and computational methods used for modelling the spatial distribution proposals were defined. The database selected for this exercise were Scielo (www.scielo.org), Science Direct (www.sciencedirect.com), Scopus (www.scopus.com), CAPES Periodicals (www.periodicos.capes.gov.br), SAE (www.sae.org/publications/technicalpapers) and Google Scholar (www.scholar.google.com). Figure 1 indicates the steps and actions followed to proceed with the searches. After the completion of each step, the main results were indicated through summary tables and graphs and the mains outcomes are highlighted in comments. 
Figure 1: Methodology used on the search of articles on electric charging stations spatial distribution models for electrified vehicles

\begin{tabular}{|c|c|c|c|c|c|c|c|c|}
\hline Step & 1 & \multicolumn{2}{|c|}{2} & \multicolumn{2}{|c|}{3} & \multicolumn{2}{|c|}{4} & 5 \\
\hline Action & $\begin{array}{c}\text { Specify preliminary list } \\
\text { of keywords }\end{array}$ & \multicolumn{2}{|c|}{$\begin{array}{c}\text { Define list of main } \\
\text { keywords }\end{array}$} & \multicolumn{2}{|c|}{$\begin{array}{l}\text { Search on specific } \\
\text { periodicals using } \\
\text { selected keywords }\end{array}$} & \multicolumn{2}{|c|}{$\begin{array}{c}\text { Quantify number of } \\
\text { articles published on } \\
\text { the last decade }\end{array}$} & $\begin{array}{c}\text { Identify regions where } \\
\text { articles were } \\
\text { published }\end{array}$ \\
\hline How & $\begin{array}{l}\text { - Brainstorm of main } \\
\text { keywords }\end{array}$ & \multicolumn{2}{|c|}{$\begin{array}{l}\text { - Search on selected } \\
\text { periodicals the keywords } \\
\text { from brainstorm session } \\
\text { - Select the keywords with } \\
\text { higher number of apperances } \\
\text { on articles }\end{array}$} & \multicolumn{2}{|c|}{$\begin{array}{l}\text { - Search on selected } \\
\text { periodicals with keywords } \\
\text { selected from step } 2\end{array}$} & \multicolumn{2}{|c|}{$\begin{array}{l}\text { - List the number of articles } \\
\text { returned from step } 3 \\
\text { - List the number of articles } \\
\text { from step } 3 \text { published each } \\
\text { year of last decade }\end{array}$} & $\begin{array}{l}\text { - List the reg } \\
\text { articles from } \\
\text { publi }\end{array}$ \\
\hline Step & \multicolumn{2}{|c|}{6} & \multicolumn{2}{|c|}{$I$} & \multicolumn{2}{|c|}{8} & \multicolumn{2}{|c|}{9} \\
\hline Action & \multicolumn{2}{|c|}{$\begin{array}{l}\text { Identify main } \\
\text { publication titles }\end{array}$} & \multicolumn{2}{|c|}{$\begin{array}{c}\text { Identify main modeling } \\
\text { methods of charging } \\
\text { station location }\end{array}$} & \multicolumn{2}{|c|}{$\begin{array}{l}\text { Identify main location } \\
\text { algorithms }\end{array}$} & \multicolumn{2}{|c|}{$\begin{array}{c}\text { List main variables } \\
\text { considered on the } \\
\text { models }\end{array}$} \\
\hline How & \multicolumn{2}{|c|}{$\begin{array}{l}\text { - List the main publication } \\
\text { titles based on the list from } \\
\text { step } 3\end{array}$} & \multicolumn{2}{|c|}{$\begin{array}{l}\text { - Search and list the main } \\
\text { modeling methods used in } \\
\text { the articles returned from } \\
\text { step } 3\end{array}$} & \multicolumn{2}{|c|}{$\begin{array}{l}\text { - Search and list the main } \\
\text { location algorithms used in } \\
\text { the articles returned from } \\
\text { step } 3\end{array}$} & \multicolumn{2}{|c|}{$\begin{array}{l}\text { - Search and list the main } \\
\text { variables considered on the } \\
\text { models used in the articles } \\
\text { returned from step } 3\end{array}$} \\
\hline
\end{tabular}

Source: elaborated by the article authors.

The brainstorming session to define the preliminary main keywords for the initial exploration on electric charging stations spatial distribution models presented as result the following list: EV charging, electric mobility, spatial distribution, location, infrastructure, charging station deployment, charging demand, distribution, charging station and electric vehicles. The list is intentionally simple and short so as not to compromise and reduce the number of returned articles in the exploration performed in the scientific periodicals. After a few try outs, it is noticed that a high quantity of keywords in the searches significantly decreases the number of returned articles. At this point, it was decided not to restrain the quantity of articles returned in the searches and the list of preliminary keywords was kept short in order to acquire a higher database of returned articles.

After defining the preliminary list of keywords, basic searches were performed to determine the keywords that have a higher appearance on the returned articles. The searches were performed in the same databases mentioned previously. In order to simplify the analysis on the publication titles, modelling methods and location algorithms, only the articles published in the Science Direct platform were considered. To also simplify the analysis on regions publishing articles on the charging station problem, only the articles published in 2020 returned from the Science Direct platform were considered. This database was the one that most returned results after Google Scholar and it is a robust scientific directory, reason why it was the most considered to these mentioned analyses.

\section{RESULTS AND DISCUSSION}

\subsection{Number and Regions of Articles Published on the Last Decade}

Figure 2 highlights the percentage of each keyword used in the returned articles from the previously mentioned databases, following the methodology described before. 
To simplify the analyzes, only articles published in 2020 were considered. Using the 5 most used keywords identified in Figure 2, a new round of searches was performed and the number of articles by year of publication returned in each platform is listed on Figure 3.

Figure 2. Proportion of keywords used in the articles returned from the initial searches in the explored periodicals: Scielo, Science Direct, Scopus, CAPES Periodicals, SAE and Google Scholar (only articles published in 2020 were considered)

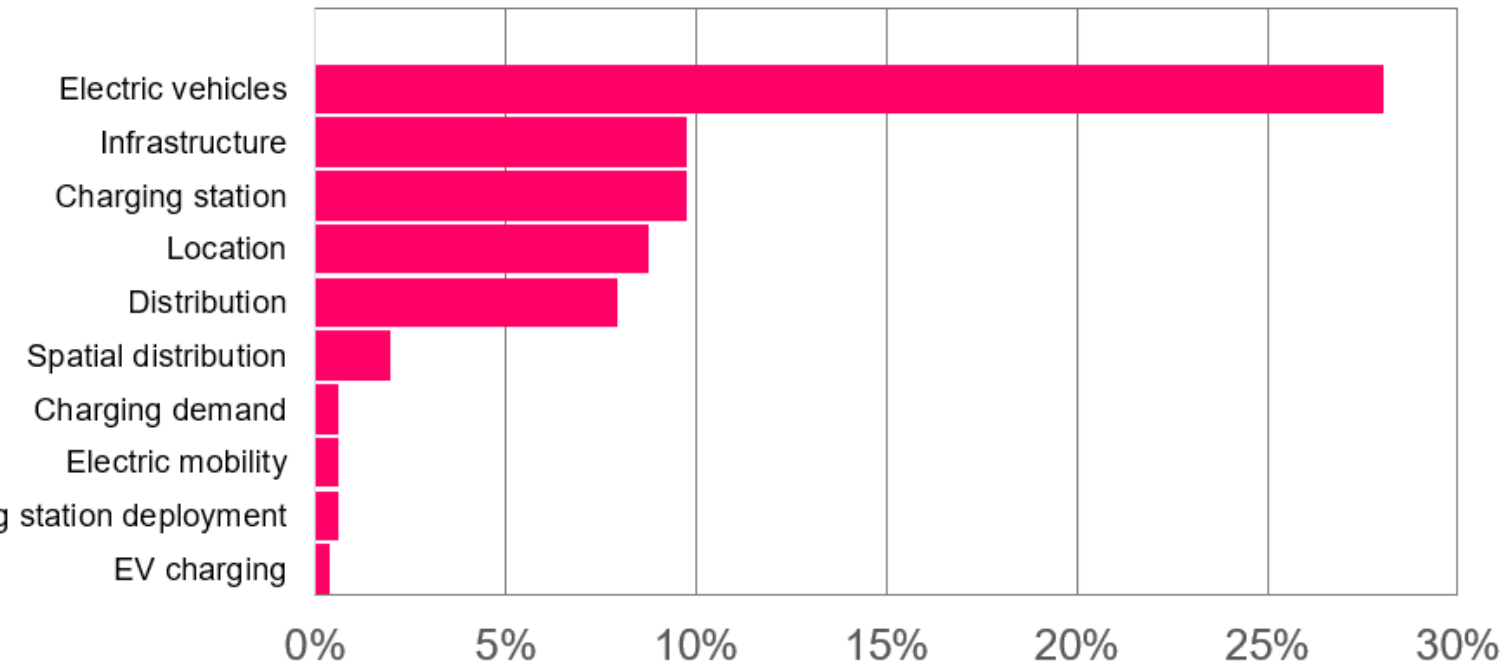

Source: elaborated by the article authors.

Figure 3: Progression on the number of results returned by each searched database using the selected keywords along the last decade

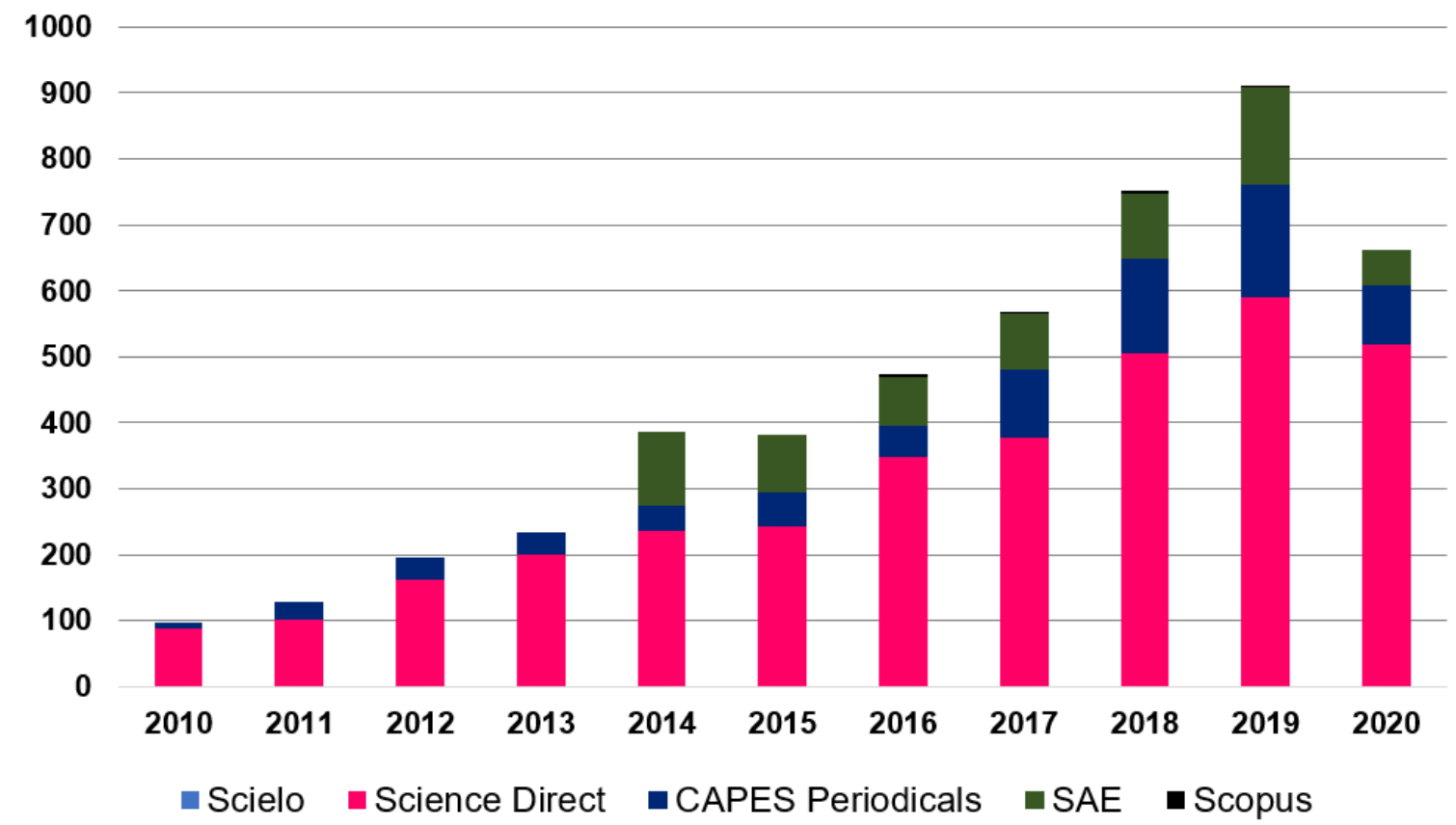

Source: elaborated by the article authors. 
Figure 3 clearly indicates that the charging station location problem has become a research hotspot in the last decade. By 2010, approximately 100 articles were published in the selected periodicals and, after 9 years, these numbers were up to approximately 900 articles (excluding Google Scholar). Figure 3 also indicates that this subject is still not saturated in the academy, presenting higher numbers of published articles year after year. It is important to highlight that even in the $S A E$ platform, which is an automotive engineering focused periodical, this tendency is also noticed - one more evidence that the researches are increasing and becoming more present based on the last decade data.

As a result to the method described in the methodology session for the analysis on regions publishing articles on the charging station problem, Europe (37\%) and Asia $(35 \%)$ are the main regions where the electric charging stations spatial distribution models for electrified vehicles articles are being published, followed by North America $(23 \%)$. South America (5\%) is the region that least produces articles on this subject and there were not found articles on other regions.

\subsection{Publication Titles, Modelling Methods and Location Algorithms}

Figure 4 indicates that "Renewable and Sustainable Energy Reviews" together with "Applied Energy" were the main publication titles on the electric charging stations spatial distribution models theme. "Energy Policy", "Energy", "Transportation Research: Transport and Environment" and "Journal of Cleaner Production" also seem to have an important influence on the publications.

Figure 4. Main publication titles on location and distribution of charging stations

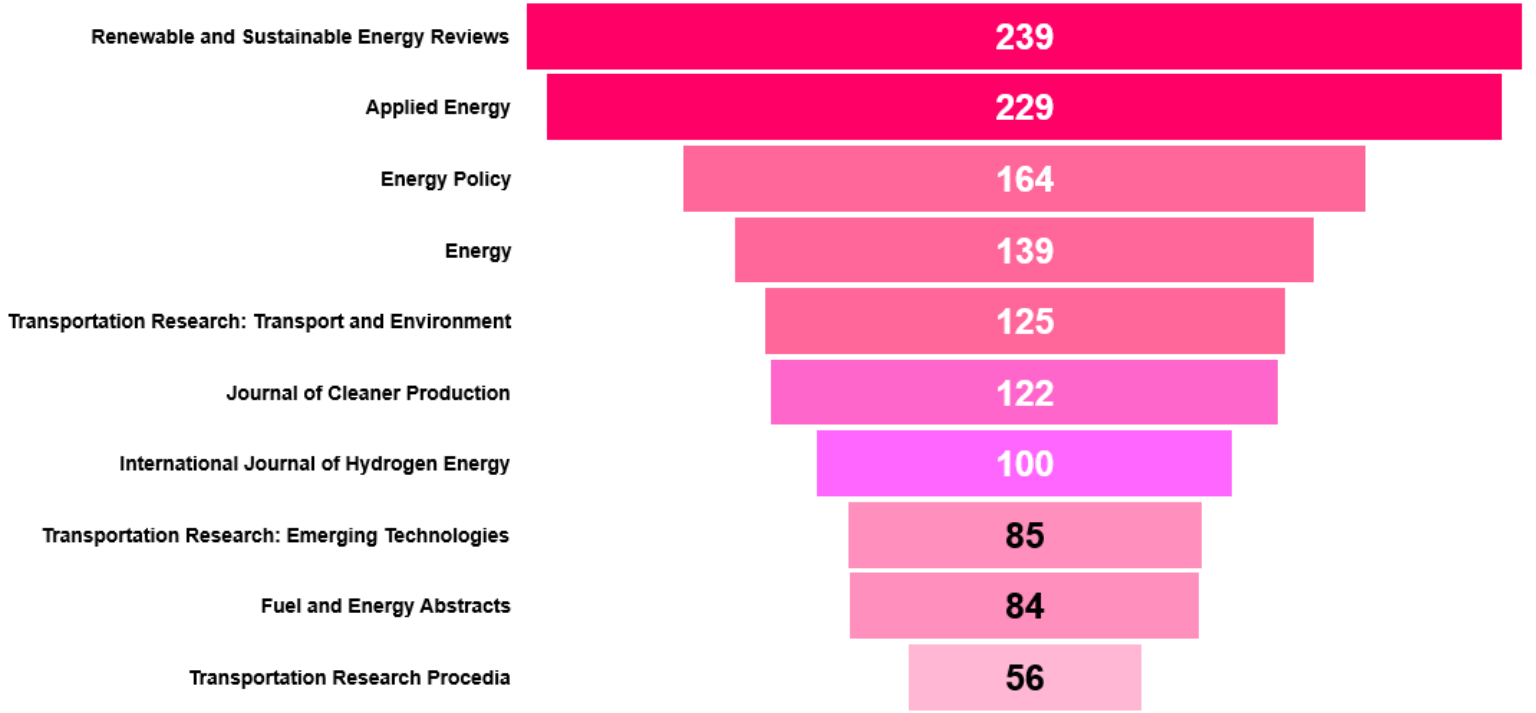

Source: elaborated by the article authors.

The review presented by Zhang et al. (2019) is an useful source of information on the state of the art for the charging station location problem. Point demand, traffic demand (FLCM), mixed models (FRLM, FCLP) and multilevel and interdisciplinary models (Game theory, Queuing theory, Delphi method, Grey hierarchical analysis - 
GAHP) are the main modeling methods; on the other hand, Traditional Algorithm (Genetic Algorithm, Particle Swarm Optimization, Tabu Search, Simulated Annealing, Alternate Location Allocation Algorithm), Improved Algorithm (Clustering, Fuzzy, Multigroup hybrid genetic algorithm - MPHGA), Artificial Neural Network and Computational Geometry are the main location algorithms [36]. A search was conducted with these modeling methods and location algorithms used and, or mentioned in the articles published in 2020 returned from the Science Direct platform (Figure 3).

Figure 5 shows the proportion of articles, published in 2020 released in Science Direct, that used and, or mentioned the modeling methods listed above. Figure 6 actually shows the number of articles that used and, or mentioned the location algorithms listed above. Traffic demand (Flow Capturing Location Model - FCLM) and Clustering seem to be the most used modeling method and location algorithm, respectively. Although this is a superficial analysis that requires a better deep dive on the data, it is an indicative on the tools being used in the most recent articles published on the charging stations location problem.

Figure 5: Modeling methods of charging station location - percentage proportion from charging station articles published in 2020 in the Science Direct database platform.

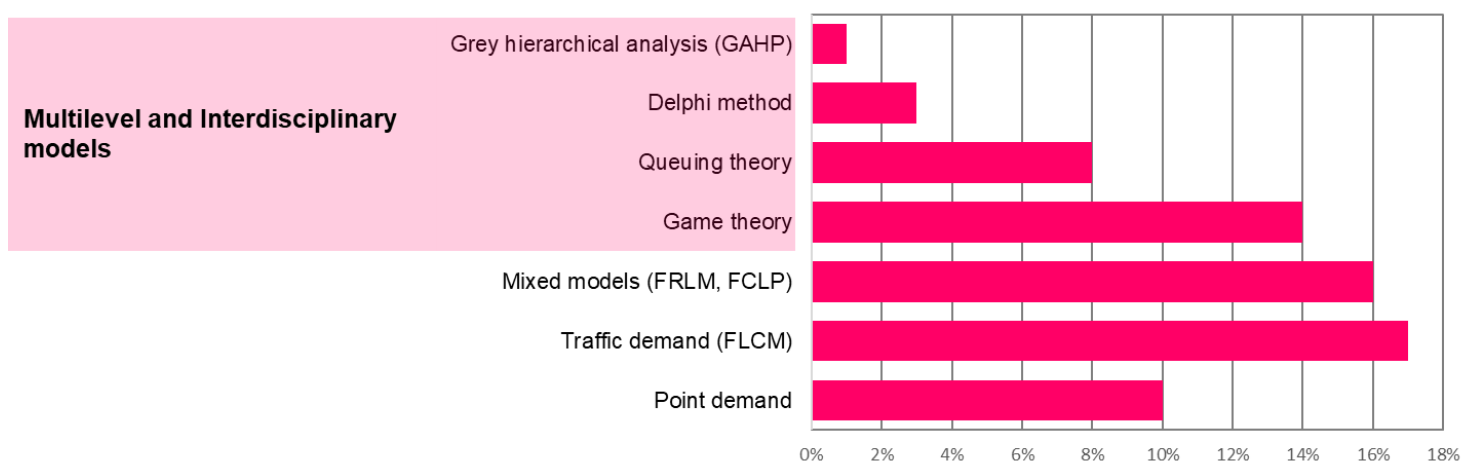

Source: elaborated by the article authors.

Figure 6: Location Algorithm - number of charging station articles published in 2020 in the Science Direct database platform.

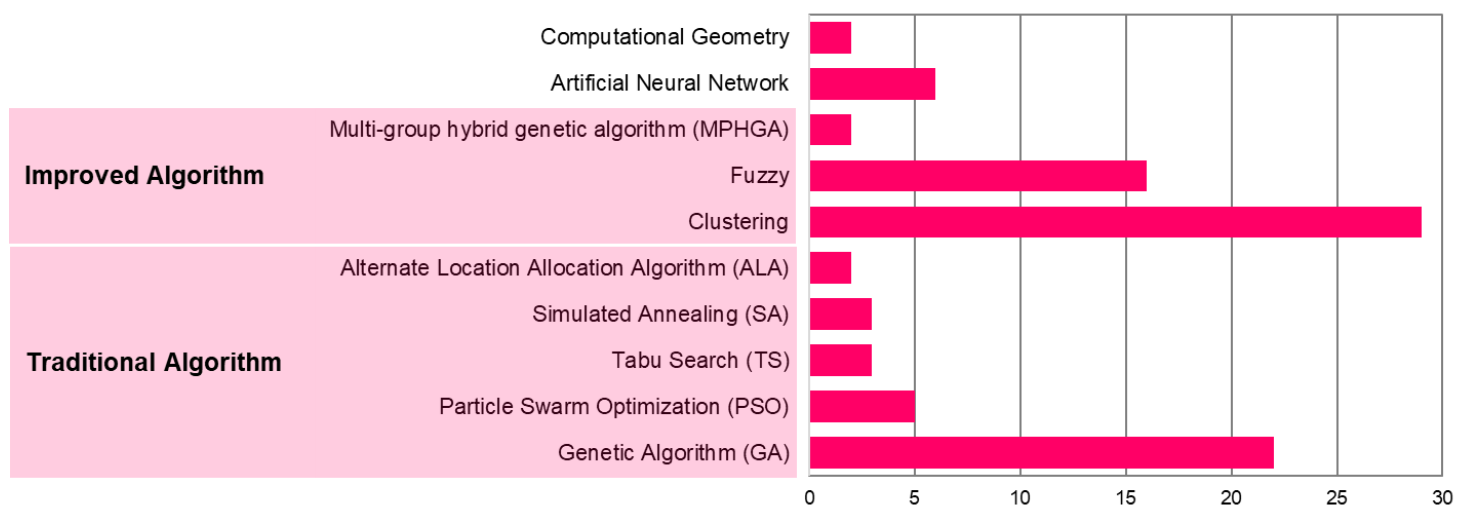

Source: elaborated by the article authors. 


\subsection{Main Variables Considered on the Models}

Considering the main variables for the charging station problem [1-36], a brief search was conducted on which variables were used in the articles database from Figure 3. Here, once again, the Science Direct platform was used due to its convenience and ease of usage. Figure 7 summarizes the main variables used and, or mentioned on that database.

Figure 7. Main variables considered in the development of electric charging stations spatial distribution models for electrified vehicles.
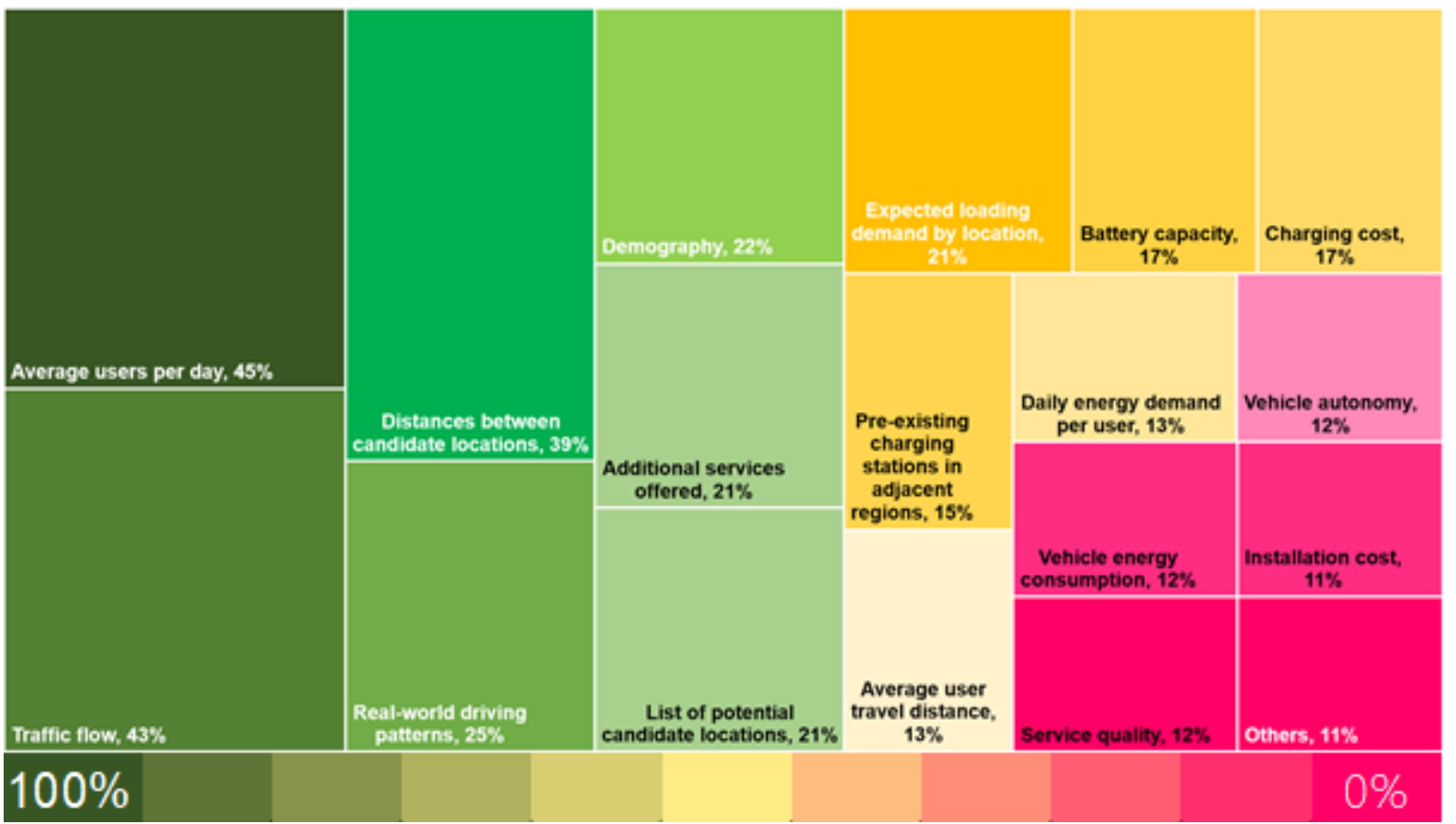

Source: elaborated by the article authors.

\section{CONCLUSION}

The location problem for electrified vehicles charging stations has become a research hotspot in the last decade with innumerous articles, studies and methods being explored and published with growing numbers throughout the past years. This paper successfully enumerated the main modeling methods, location algorithms and variables used for developing such location models, quantifying the proportion in which these variables are used in the most recent published articles.

As per the results from the brief literature review explored on this paper, it is possible to conclude that Traffic Demand (FLCM) is the main modeling method being used together with clustering as the mechanism for location algorithms in the recent published papers. Average users per day and traffic flow are the main variables considered in such location models for electrified vehicles charging stations. It is also possible to conclude that there is room for new developments and publications using 
big data and artificial neural networks since these are growing techniques and have not been highlighted as the main models published in the last decade.

These findings are significant to drive new researchers on this topic and can be used as comprehensive information for beginners on this area, giving directions on main models, location algorithms and variables to be evaluated and considered for the development or adjustment of new location models.

\section{REFERENCES}

${ }^{1}$ KAPUSTIN, Nikita O., and Dmitry A. Grushevenko. "Long-term electric vehicles outlook and their potential impact on electric grid." Energy Policy 137 (2020): 111103. ${ }^{2}$ ADNAN, N., Nordin, S. M., Rahman, I., Vasant, P., \& Noor, M. A. "An overview of electric vehicle technology. A vision towards sustainable". Green marketing and environmental responsibility in modern corporations. 216. (2017)

${ }^{3}$ OECD/IEA. "Scaling up the Transition to Electric Mobility". https://mww.iea.org/publications/reports/globalevoutlook2019/. Global EV Outlook 2019. Accessed 10 July 2020.

${ }^{4}$ LIEVEN, Theo, and Nele Rietmann. "Forecasting the trajectory of electric vehicle sales and the consequences for worldwide CO2 emiss ions." Journal of Cleaner Production (2020): 121038.

${ }^{5}$ FRADE, Inês, et al. Optimal location of charging stations for electric vehicles in a neighborhood in Lisbon, Portugal. Transportation Research Record 2252.1 (2011): 91 98.

${ }^{6}$ DE GENNARO, Michele, Elena Paffumi, and Giorgio Martini. Customer-driven design of the recharge infrastructure and Vehicle-to-Grid in urban areas: A large-scale application for electric vehicles deployment. Energy 82 (2015): 294-311.

${ }^{7}$ BARESCH, Martin, and Simon Moser. "Allocation of e-car charging: Assessing the utilization of charging infrastructures by location." Transportation Research Part A Policy and Practice 124 (2019): 388-395.

${ }^{8}$ ANDRENACCI, Natascia, Roberto Ragona, and Gaetano Valenti. A demand-side approach to the optimal deployment of electric vehicle charging stations in metropolitan areas. Applied Energy 182 (2016): 39-46.

${ }^{9}$ CSONKA, Bálint, and Csaba Csiszár. Determination of charging infrastructure location for electric vehicles. Transportation Research Procedia 27 (2017): $768-775$.

${ }^{10}$ EFTHYMIOU, Dimitrios, et al. Electric vehicles charging infrastructure location: a genetic algorithm approach. European Transport Research Review9.2 (2017): 1-9.

${ }^{11} \mathrm{XIAO}$, Dan, Shi An, Hua Cai, Jian Wang, and Haiming Cai. "An optimization model for electric vehicle charging infrastructure planning considering queuing behavior with finite queue leng th." Journal of Energy Storage 29 (2020): 101317.

${ }^{12}$ SACHAN, Sulabh, Sanchari Deb, and Sri Niwas Singh. "Different charging infrastructures along with smart charging strategies for electric vehicles." Sustainable Cities and Society (2020): 102238.

${ }^{13}$ BRÄUNL, Thomas, David Harries, Mark McHenry, and Guido Wager. "Determining the optimal electric vehicle DC-charg ing infrastructure for Western

Australia." Transportation Research Part D: Transport and Environment 84 (2020): 102250.

${ }^{14} \mathrm{NAPOLI}$, Giuseppe, Antonio Polimeni, Salvatore Micari, Laura Andaloro, and Vincenzo Antonucci. "Optimal allocation of electric vehicle charging stations in a highway network Part 1. Methodology and test application." Journal of Energy Storage 27 (2020): 101102.

${ }^{15}$ PAN, Long, Enjian Yao, Yang Yang, and Rui Zhang. "A location model for electric vehicle (EV) public charging stations based on drivers' existing activities." Sustainable Cities and Society (2020): 102192.

${ }^{16}$ DAS, H. S., M. M. Rahman, S. Li, and C. W. Tan. "Electric vehicles standards, charg ing infrastructure, and impact on grid integ ration: A technological review." Renewable and Sustainable Energy Reviews 120 (2020): 109618.

${ }^{17}$ ANJOS, Miguel F., Bernard Gendron, and Martim Joyce-Moniz. "Increasing electric vehicle adoption through the optimal deployment of fast-charging stations for local and long-distance travel." European Journal of Operational Research (2020).

${ }^{18}$ ZHANG, Yu, Xiangtao Liu, Tianle Zhang, and Zhaoquan Gu. "Review of the Electric Vehicle Charging Station Location Problem." In International Conferenœ on Dependability in Sensor, Cloud, and Big Data Systems and Applications, pp. 435-445. Springer, Singapore, 2019.

${ }^{19}$ RODRíGUEZ, R., N. Vidal, and E. Zabala. Added value services for EV charging manag ement. 2013 World Electric Vehicle Symposium and Exhibition (EVS27). IEII 2013.

${ }^{20}$ SATHAYE, Nakul, and Scott Kelley. An approach for the optimal planning of electric vehicle infrastructure for highway corridors. Transportation Research Part E Logistics and Transportation Review59 (2013): 15-33.

${ }^{21}$ TAN, Jingzi, and Wei-Hua Lin. A stochastic flow capturing location and allocation model for siting electric vehicle charg ing stations. 17th International IEEE Conferenœ on Intelligent Transportation Systems (ITSC). IEEE, 2014.

${ }^{22}$ GONZALES J, Alvaro R, Gamallo C, Fuentes M, Fraile-Ardanuy J, Knapen L, et al. Deterring electric vehicles charging point location considering drivers' daily acti vities. Proc Comput Sci 2014; 32:647-54.

${ }^{23}$ BAOUCHE, Fouad, et al. Efficient allocation of electric vehicles charging stations: Optimization model and application to a dense urban network IEEE Intelligent transportation systems magazine $6.3(2014): 33-43$.

${ }^{24}$ SADEGHI-BARZANI, Payam, Abbas Rajabi-Ghahnavieh, and Hosein Kazemi-Karegar. Optimal fastcharging station placing and sizing. Applied Energy 125 (2014): $289-$ 299.

${ }^{25} \mathrm{CAl}$, Hua, et al. Siting public electric vehicle charging stations in Beijing using big -data informed travel patterns of the tax fleet. Transportation Research Part D: Transport and Environment 33 (2014): 39-46.

${ }^{26}$ BROOKER, R. Paul, and Nan Qin. Identification of potential locations of electric vehicle supply equipment. Journal of Power Sources 299 (2015): 76-84.

${ }^{27} \mathrm{GUO}$, Sen, and Huiru Zhao. Optimal site selection of electric vehicle charging station by using fuzzy TOPSIS based on sustainabil ity perspective. Applied Energy 158 (2015): 390-402.

${ }^{28} \mathrm{WU}$, Yunna, et al. Optimal site selection of electric vehicle charging stations based on a cloud model and the PROMETHEE method. Energies 9.3 (2016): 157.

${ }^{29}$ DAVIDOV, Sreten, and Miloš Pantoš. Planning of electric vehicle infrastructure based on charging reliability and quality of service. Energy 118 (2017): $1156-1167$.

${ }^{30}$ VISWANATHAN, Shekar, et al. Development of an assessment model for predicting public electric vehicle charging stations. European Transport Research Review 10.2 (2018): 54 .

${ }^{31}$ BARESCH, Martin, and Simon Moser. "Allocation of e-car charging: Assessing the utilization of charging infrastructures by location." Transportation Research Part A: Policy and Practice 124 (2019): 388-395.

32 XIAO, Dan, Shi An, Hua Cai, Jian Wang, and Haiming Cai. "An optimization model for electric vehicle charging infrastructure planning considering queuing behavior with finite queue leng th." Journal of EnergyStorage 29 (2020): 101317.

${ }^{33}$ RICHARDSON, David B. "Electric vehicles and the electric grid: A review of modeling approaches, Impacts, and renewable energy integration. "Renewable and Sustainable Energy Reviews 19 (2013): 247-254.

${ }^{34} \mathrm{XI}$, Xiaomin, Ramteen Sioshansi, and Vincenzo Marano. Simulation-optimization model for location of a public electric vehicle charging infrastructure. Transportation Research Part D: Transport and Environment 22 (2013): 60-69.

${ }^{35} \mathrm{HE}$, Fang, et al. Optimal deployment of public charging stations for plug-in hybrid electric vehicles. Transportation Research Part B: Methodological 47 (2013): $87-101$.

${ }^{36}$ ZHANG, Yu, Xiangtao Liu, Tianle Zhang, and Zhaoquan Gu. "Review of the Electric Vehicle Charging Station Location Problem." In International Conference on Dependability in Sensor, Cloud, and Big Data Systems and Applications, pp. 435-445. Spring er, Sing apore, 2019. 